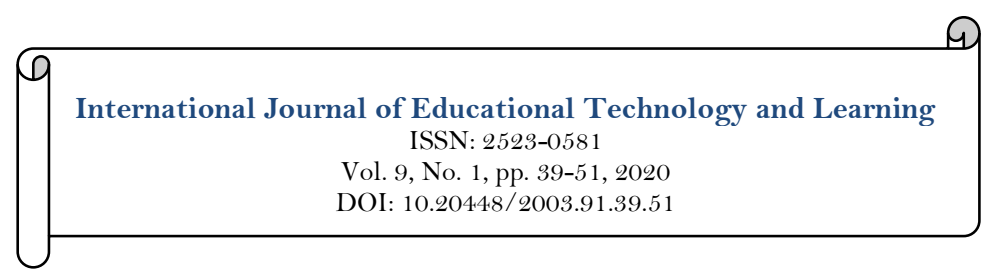

\title{
A Case Study on How Children Develop Computational Thinking Collaboratively with Robotics Toys
}

\author{
Kay Yong Khoo \\ Faculty of Education, The University of Hong Kong, Hong Kong SAR. \\ Email:khooky@hku.hk
}

\begin{tabular}{|c|c|}
\hline Abstract & \\
\hline $\begin{array}{l}\text { This article reports on a case study on how robotics toys provide the } \\
\text { affordances for developing computational thinking (henceforth abbreviated } \\
\text { to CT) in young learners. The three key constructs of CT -abstraction, } \\
\text { algorithms and automation - are used in the research. The study results } \\
\text { identify how children interact with robotics toys collaboratively and acquire } \\
\text { CT skills. Problems were presented to the children through planned non- } \\
\text { routine and immersive collaborative group activities. The Situations in } \\
\text { which they externalised their inquiries and internalised new knowledge were } \\
\text { observed. A detailed examination of the data collected was made to } \\
\text { determine which robotics toys mediated the children's acquisition while } \\
\text { seamlessly switching between individual and collaborative activities and has } \\
\text { led to the development of a framework of the stages in CT learning designs. } \\
\text { This paper synthesises the relevant classroom activity designs in addressing } \\
\text { CT as a general term that involves solving problems, entails a whole set of } \\
\text { mental tools that enable people to reduce complex problems into readily } \\
\text { solvable subtasks and composes algorithms that are executable by machines. } \\
\text { Moreover, the article will also include details and analyses of the selection of } \\
\text { commercially available technologies for developing CT in the young learners } \\
\text { in the study. }\end{array}$ & $\begin{array}{l}\text { Licensed: } \\
\text { This work is licensed under a } \\
\text { Creative Commons Attribution } 4.0 \\
\text { License. } \\
\text { Publisher: } \\
\text { Scientific Publishing Institute }\end{array}$ \\
\hline
\end{tabular}

Funding: This study received no specific financial support.

Competing Interests: The author declares that there are no conflicts of interests regarding the publication of this paper.

Acknowledgement: An early version of this article was presented at the Annual Conference of the Mobile Learning Festival in June, 2018.

\section{Introduction}

CT) is broadly defined as the ability to abstract problems and formulate solutions that can be automated (Kurilovas \& Dagiene, 2016). Like reading, writing and mathematics, CT develops children's analytical skills (Harangus \& Kátai, 2017). In an increasingly information-based society, CT is viewed as an essential problemsolving skill. Although CT has received considerable attention over the past several years, there is little agreement on how it might be incorporated in early education (Manches \& Plowman, 2017).

There are many robotics toys out in the market that help students understand various concepts. These interactive toys encourage cognitive development in children at a young age. Since collaborative problemsolving skills are fundamental to the functioning of modern societies, they should be supported and practised in education systems. Hence, constructivist teaching approaches are considered to have the potential to help foster the 21 st-century skills we require of young people (Cukurova, Luckin, Millán, \& Mavrikis, 2018). When young children are involved in a group learning activity utilising a robotics toy, they seem to perceive that the 
robotics toy has psychological attributes. They work in unison to solve a problem by interacting with the robotics toy through its technological features (Sung, 2018).

Activities designed for children engaged with robotics toys provide a context and set of opportunities that provide a basis for active conversations about computational thinking. There is currently avid interest among educators in the ways that design-based learning activities support the development of CT in young people. Part of this interest is fuelled by the growing availability of tools that enable young people to independently solve problems. More importantly, however, this interest is rooted in a commitment to learning through design activities, a constructionist approach to learning that highlights the importance of young people engaging in the development of external artefacts.

\subsection{Computational Thinking Concepts}

As young children participate in learning activities with educational robotics toys, they engage with a set of computational concepts that are common in many programming languages. Wing (2006) argued that CT involves three key constructs: Algorithms, Abstraction, and Automation. Algorithms refer to the arrangement of a step-by-step series of instructions to execute a task or solve a problem. In the current research, the Code and Go Robot Mouse exemplify the use of algorithms through the use of a set of worksheets; Abstraction involves the ability to decide and consolidate the relevance by ignoring the irrelevance, and is exemplified by the use of the $3 \mathrm{D}$ pen with worksheets; and Automation involves the use of computers/machines by applying codes to do recursive duties, as is exemplified by the OZO-Bot robot (with different colours and speed of movements) and worksheets.

\section{Methods}

The current study seeks to analyse informative and evidence-based findings to give an insight on how children acquire CT knowledge through collaborative activities with robotics toys. The individual interactions were situated in a context, which constitutes the activity as a unit of analysis. Analysis of individual activity must take into account of various artefacts that mediate between the components of the activity in which it occurs. The activity theory (Engeström, 1987) was selected as the theoretical framework best applicable in the contexts of learning studied here see Figure 1.

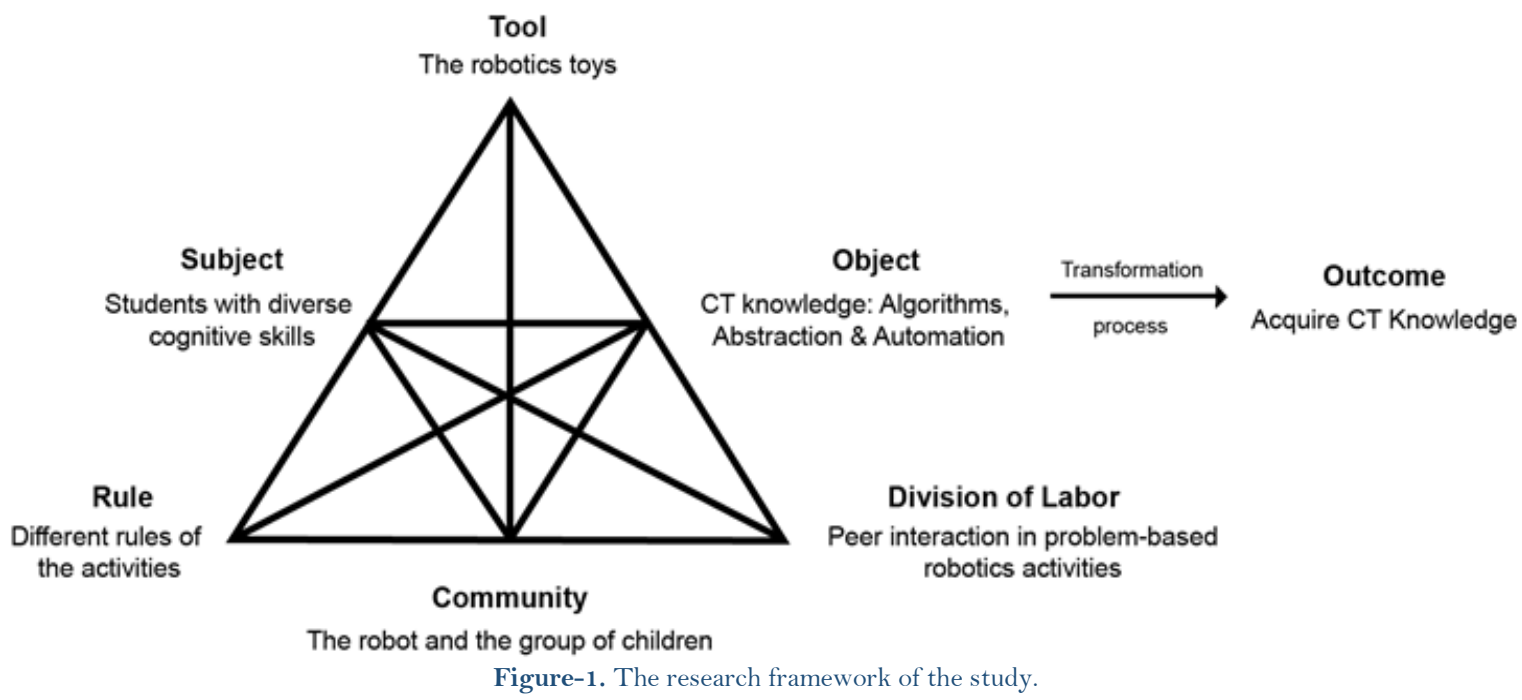

The study employs a qualitative research approach that is both descriptive and exploratory. To gain a more in depth and generalizable result, a multiple case study research approach was conducted to independently confirm emerging constructs and propositions, while at the same time revealing complementary aspects of the phenomena of interest (Yin, 2014). The study data were collected through video recordings, observations and interviews, and employed an inductive research strategy that intuitively developed abstractions from the research (Merriam, 1988). Two research questions emerging from the literature reviews guided the data collection and analysis of the current study:

(1) How do robotic toys facilitate collaboration in learning CT constructs?

(2) What elements of problem-based collaborative activities might contribute to or obstruct children CT learning?

The study applied the Activity framework as an analytical tool to investigate the phenomena of interest as incorporated in the research questions. The phenomena were derived from real-life contexts conflated with both the unit of study and the product of investigation. Data was collected over a period of eight months. The study was explorative, and a constant comparative method of data analysis was employed see Table 1. 
Table-1. Research methodology procedure and aims.

\begin{tabular}{|c|c|c|c|}
\hline $\begin{array}{l}\text { Research } \\
\text { Stages }\end{array}$ & Observations & Interviews & Analysis of students' works \\
\hline 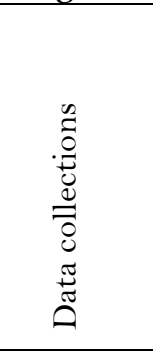 & $\begin{array}{l}\text {-To observe how the child } \\
\text { communicates in a group to } \\
\text { complete their tasks with } \\
\text { and without robotic toys. } \\
\text {-To study how the child } \\
\text { embraces the robotics toys } \\
\text { meaningfully to complete } \\
\text { the group tasks. }\end{array}$ & $\begin{array}{l}\text {-To clarify whether } \\
\text { children understand the } \\
\text { tasks before undertaking } \\
\text { the group interactions. } \\
\text {-To clarify whether } \\
\text { children understand the } \\
\text { tasks after the group } \\
\text { interactions. }\end{array}$ & $\begin{array}{l}\text {-To investigate how the child } \\
\text { completes their different types } \\
\text { of group work with and } \\
\text { without robotic toys: } \\
\text { 1. When the group members } \\
\text { have the same worksheet. } \\
\text { 2. When the group members } \\
\text { have different worksheets. }\end{array}$ \\
\hline 它 & \multicolumn{3}{|c|}{$\begin{array}{l}\text {-How do robotic toys facilitate collaboration in learning CT (the construct of algorithm, } \\
\text { abstraction and automation)? } \\
\text { - What are the elements in these problem-based collaborative learning activities that might } \\
\text { contribute to children's CT learning? } \\
\text {-What are the elements that obstruct them from CT learning? }\end{array}$} \\
\hline \multirow[t]{2}{*}{ Duration } & \multicolumn{2}{|c|}{ In 7.5 months } & \\
\hline & & \multicolumn{2}{|c|}{1 month } \\
\hline
\end{tabular}

The study commenced by gathering cases of different learning abilities and behaviours (the purposive sampling). The selection was terminated when no new information was forthcoming from sampled units during the research period. Three participants were identified according to their personalities and their learning abilities in the classrooms: their profiles are presented in Table 2. Pseudonyms are used to preserve their anonymity.

Table-2. Details derived from the selection criteria for the three cases.

\begin{tabular}{|c|c|c|c|c|c|c|}
\hline \multirow[t]{2}{*}{ Participants } & \multirow[b]{2}{*}{ Age } & \multirow[b]{2}{*}{ Gender } & \multirow[t]{2}{*}{ Group } & \multicolumn{3}{|c|}{ Types of Robotic Toys } \\
\hline & & & & Mouse Robot & OZO-Bot & 3D-Pen \\
\hline Peter & 5 & Male & A & \multirow{3}{*}{$\begin{array}{l}\text { Algorithm: } \\
\text { How they learnt } \\
\text { to design the } \\
\text { steps required to } \\
\text { complete a task }\end{array}$} & \multirow{3}{*}{$\begin{array}{l}\text { Automation: } \\
\text { The ability to } \\
\text { use digital tools } \\
\text { to mechanize } \\
\text { problem } \\
\text { solutions. }\end{array}$} & \multirow{3}{*}{$\begin{array}{l}\text { Abstraction: } \\
\text { How they } \\
\text { learnt to create } \\
\text { a } 3 \mathrm{D} \text { object and } \\
\text { developed the } \\
\text { ability to apply } \\
\text { the process in } \\
\text { other similar } \\
\text { cases }\end{array}$} \\
\hline Mary & 5 & Female & $\mathrm{B}$ & & & \\
\hline Nicole & 5 & Female & $\mathrm{C}$ & & & \\
\hline
\end{tabular}

During the 8 months' study at the kindergarten, the teacher used different robotic toys and activities in children's group practices in the classroom. The robots were introduced after a formal demonstration by the teachers. Each of the robots was used repeatedly two to four times per month. All the children were given the opportunity to use the appropriate robot in completing the group problem-solving activities. Three types of robots were selected for the current study: Mouse Robot, 3D Pen and OZO-bot. These robots were selected based on the unique characteristics of the instructions they applied in learning different constructs of CT see Figures $2 \mathrm{~A}, 2 \mathrm{~B}$ and $2 \mathrm{C}$.

The steps to follow in the following activities:

1. The teacher demonstrates how to use the robot.

2. There are 12 children in the class, divided into 4 groups of three.

3. There are 3 activities for MR, 4 activities for $3 \mathrm{D}$ pen and 2 activities for OZOBOT.

4. The time allocation for each activity is 15 minutes.

5. When the time is up, the teacher announces the team with the highest score.

The activity: Mouse Robot (MR).

There are directional buttons at the back of the mouse, i.e., forward, left, right, backward, clear, execute and etc. In activity 1, each group will receive one piece of $\mathrm{M} 1$ and one of $\mathrm{M} 2$ (the children will share one set of questions). The teacher will always ask the children to guess the answers and write them in the circles. Then, the teacher places one set of MR with each group. The children will then take turns to test the MR and compare it with their answers. In activity 2 , each group will receive one piece of M1 and each child will receive one piece of M3 (each M3 is with different questions). The teacher will always ask the children to guess the answers by drawing the directions in the boxes. Then, the teacher places one set of MR with each group. The 
children will then take turns to test the MR and compare it with their answers. In activity 3, there are 12 shops on the M4 map. There are 2 questions in the M5 worksheet.

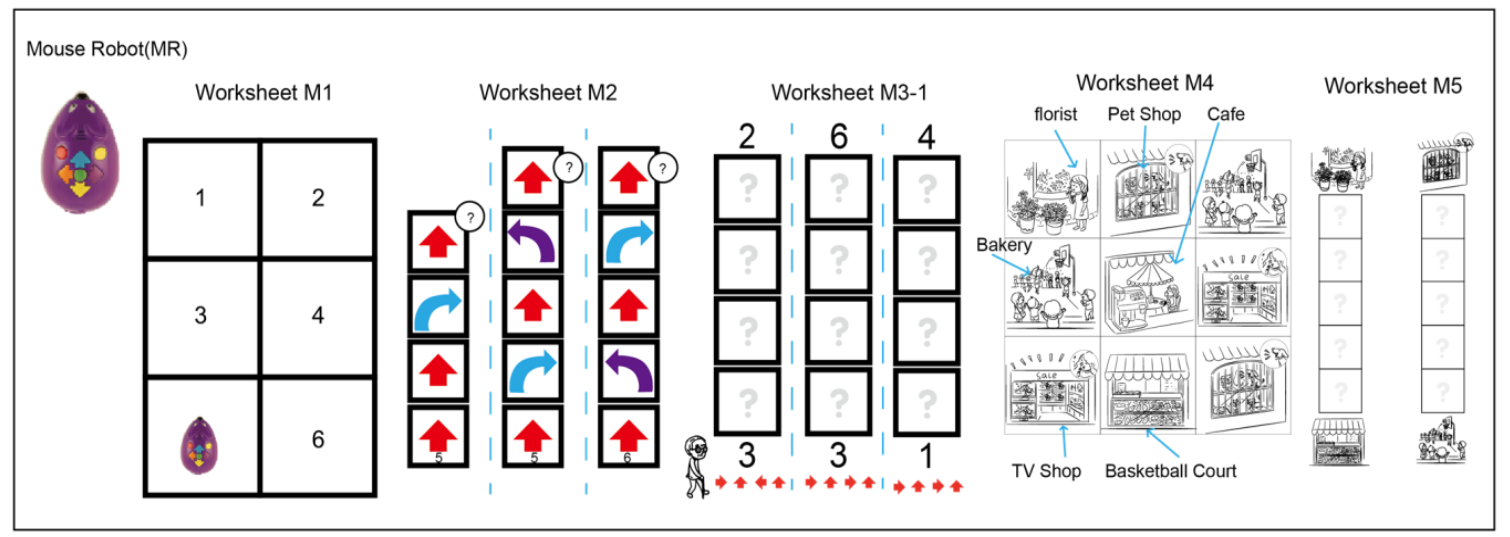

Figure-2A. The Educational Robotics Activity (Mouse Robot).

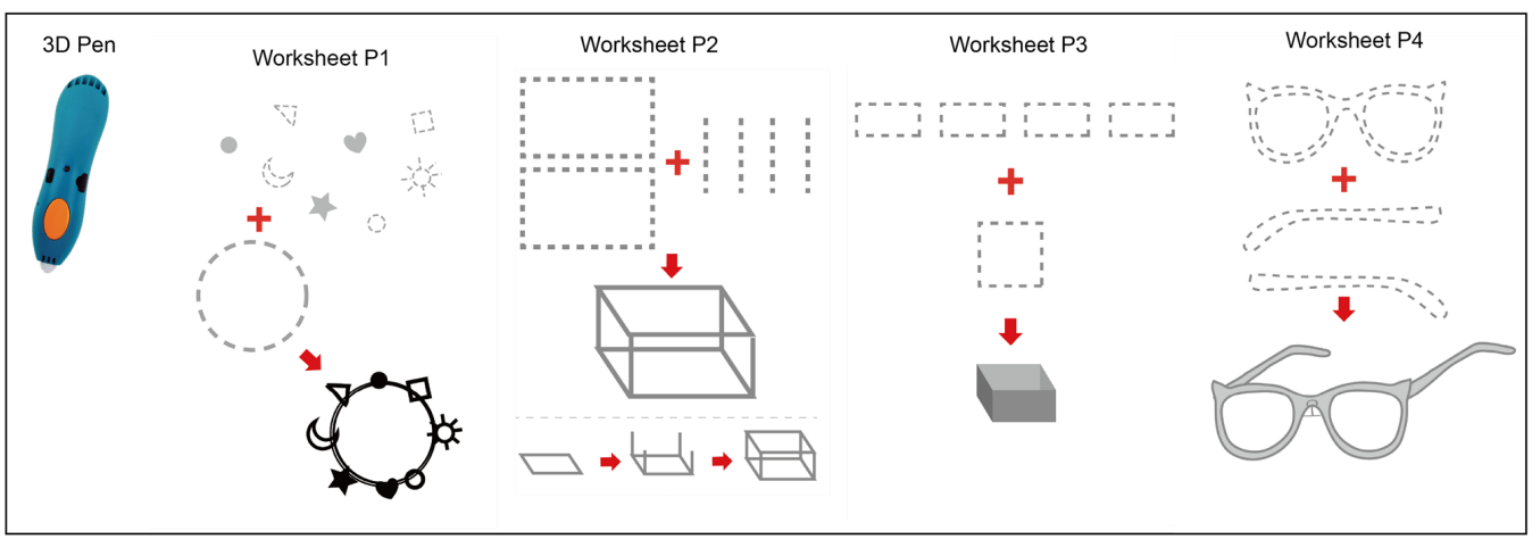

Figure-2B. The Educational Robotics Activity (3D Pen).

The activity: $3 \mathrm{D}$ Pen

Activities 1,2 \& 3

Use the $3 \mathrm{D}$ pen to trace the dotted lines in $\mathrm{P} 1, \mathrm{P} 2$ and $\mathrm{P} 3$. Press the orange button as you are tracing the lines of the worksheet. The $3 \mathrm{D}$ pen will release plastic gel and turns hard instantly. Then, the ring can be formed, along with other smaller items (in $\mathrm{P} 1$ ), the rectangular objects and lines (in $\mathrm{P} 2$ ) and rectangular object (in P3).

In Activity 4 the participant forms the pair of glasses with the $3 \mathrm{D}$ pen and places it on their own creations.

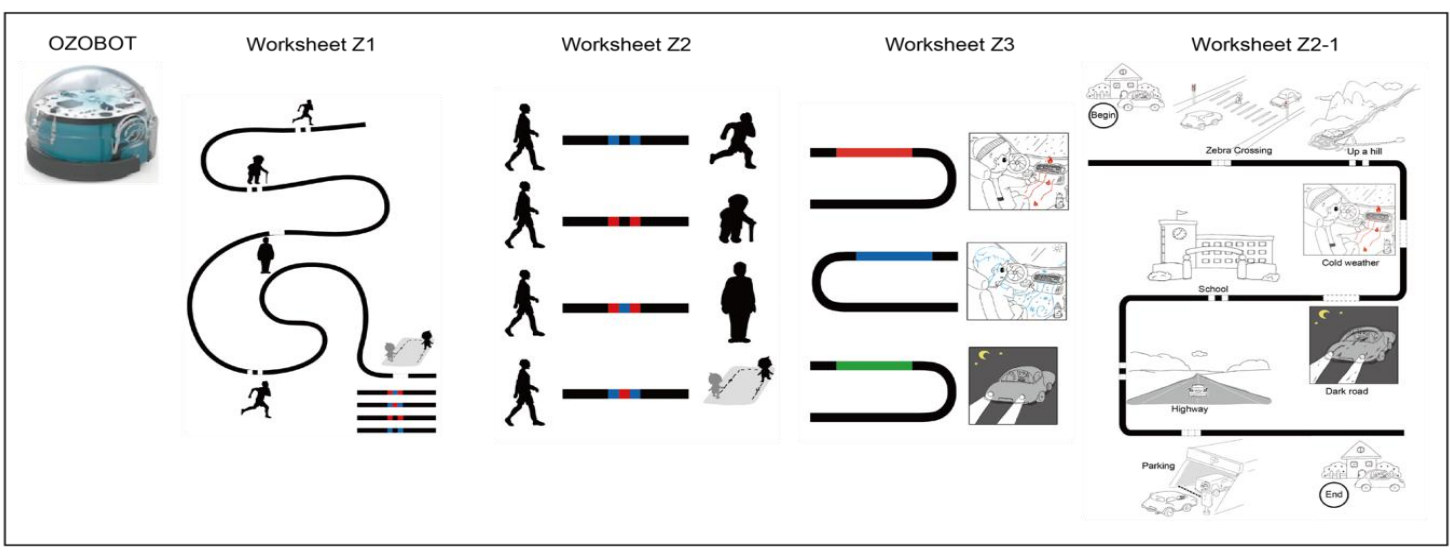

Figure-2C. The Educational Robotics Activity (OZOBOT) 
The activity: OZOBOT

There are 2 activities. The activities treat the OZOBOT as a car. The participants use different codes to set OZOBOT as it travels.

Activity 1

As illustrated in Z3, the OZOBOT travels on the thick line. In the middle of the line, in the "blue-blackblue" portion, the speed of the OZOBOT will change from normal to fast ("red-black-red": normal to slow; "red-blue-red": normal to pause; "blue-red-blue": normal to reversing movement). The participant is requested to colour $\mathrm{Z}_{1}$ along the path according to the symbols given. They then let the OZOBOT travel along the path and observe the changes of the movement as it passes points at which different codes apply.

Activity 2

The OZOBOT will always default to blue light. However, there are some codes to change the colour. As illustrated in $\mathrm{Z} 4$, the long red will change the colour to red (which denotes the vehicle to turn on the heater), blue (which denotes the vehicle to turn on the air-conditioner), and green which denotes the vehicle to turn on the car front lamp). There are three different worksheets of $\mathrm{Z}_{2}$, each participant in the group will receive a different set of question. The participant judges how to apply different codes as the OZOBOT passes different locations.

\section{Results}

\subsection{Participant one: Peter}

Peter was an outgoing child, asking questions spontaneously of his teammates in the group whenever doubts arose in his mind. His recent math assessment result was about average. He joined the robotic lessons in his kindergarten. The current research focused on three different types of robot-mediated activities. In the first set of activities with MR see Figure 2A, he was assigned to a group of three in which the other two members were more mathematically advanced than him. In activity 1 using the robot MR, the teacher gave the team M1, and Peter and the other two members of his group were given M2 separately. The lesson started with the group guessing the answers to questions referring to M1. Peter did not pay attention to the questions but sought to listen and observe how the other two team members pointed at the boxes in M1 and wrote the answers. He copied the behaviour of his peers, and their answers. Once the group had completed the three questions concerning $\mathrm{M} 2$, they were given the robot. It took them a while to figure out how to operate it. Peter took the initiative and was the first to try. When doing so, he referred to the questions and followed the directions of his team members, with some success. The situation demonstrated the process of peer learning (Liu \& Carless, 2006) mediated in the context of operating the robot. In activity 2 using the robot MR, when it was Peter's turn to use the robot to compare with his answers, the team members pushed him to act faster, and guided him in answering his questions. After some attempts, Peter realised his mistakes and corrected them accordingly. Finally, he managed to correctly answer the last question on his own. In activity 3 with MR, Peter was seen to complete his questions without assistance. Then, when using the robot to execute their steps, Peter started to observe and compare his answers with the team members. He acknowledged that one of his team members managed to find shorter routes to the answers than him.

In the next set of activities, Peter's team were given a 3D pen (see Figure $2 \mathrm{~B}$ ). They received worksheets $\mathrm{P}_{1}, \mathrm{P}_{2}, \mathrm{P}_{3}$ and $\mathrm{P}_{4}$ in the four consecutive activities (see Figure 2B). In activity 2, when Peter encountered doubts he asked and observed how the other team members added $2 \mathrm{D}$ lines to the $2 \mathrm{D}$ rectangles. In activity 3 , he filled the 6 rectangular surfaces and put them together to form a cuboid by regularly seeking assistance from his team members. In the $4^{\text {th }}$ activity, he observed how other team members started their activities, then reconfirmed the steps with them.

The following snippets of conversation took place during the $4^{\text {th }}$ lesson.

Peter: "Frank, do we start with the round frame first, then create the two temples?"

Frank: "Yes, exactly!"

Peter: "How do we create the lens inside the frame?"

Frank: "You do like last time when we created the box."

Peter: "Then, we place them flat and join them with the pen like we did last time."

Peter eventually completed the glasses on his own.

In the third set of activities with OZO-bot robot (see Figure $2 \mathrm{C}$ ), they started with activity 1 . The team was given one piece of $Z_{1}$ and each member had one $Z 3$ individually. The teacher explained to them that there were three different codes, i.e., "Blue-Black-Blue" (it represented "fast movement"), "Red-Black-Red" (it represented "slow movement"), "Red-Blue-Red" (it represents "pausing") and "Blue-Red-Blue" (it represents "reversing movement") at the beginning of the lesson. Peter could follow the codes as showed in $Z_{1}$ and coloured the worksheet $\mathrm{Z}$ 3. As he was doing it, the team members saw the movement of the robot (e.g. slow) and they discussed while saying the codes loudly (e.g., red-black-red) as the robot was moving over the different codes along the path in Z3. When it was other members' turn, Peter also said the codes loudly (e.g. "Red-Black-Red"). When the team proceeded in activity 2 (with Z4 one piece they shared among the team and each of the member had separate and different worksheets, Z2-1, Z2-2 and Z2-3). The teacher briefed them the 
codes, Red: turn on the air-conditioner inside the car, Blue- turn on the heater inside the car and Green-switch on the light of the car. They shared the robot in activity 2. They coloured the paths according to the different coding as in $\mathrm{Z} 4$, then they took turn to test the robot with their codes. They observed other team members' codes when it was not their turn. They could say the codes intuitively "Blue", "Red", "Green", "Blue-BlackBlue" and etc. as they saw the new situations on other members' worksheets. They could complete the activity correctly. Peter could still remember the codes even after the lesson during the interview.

Participant Two: Mary

Mary had an easy-going manner and demonstrated good social assertive skills in the class. She had scored good results in her schoolwork in mathematics and was very helpful to her classmates when asked for assistance. She joined the group of three. In the activity 1 with MR (see Figure 2A), she completed her worksheet and when the teacher gave the robot to the team, she helped her group members to use the robot with their works. She explained and commented on their answers. She was the last one to use the robot in the group. And when it was her turn, she did not use the robot. However, she managed to change her answers after helping the other members with the robot. In activity 2 of $\mathrm{MR}$, she observed and guided other team members to complete their work and tested the answers with the robot. Each member had a different set of questions in activity 2. All the attention of the three members was at the robot as they took turn to use it to access their answers. When it was Mary's turn. She did not use the robot. She could answer the questions correctly. In activity 3 with MR, one piece of M4 was given to the group. all of them started by looking at M4 and answered their individual questions, i.e. M5. As told by the teacher, they should find the routes from one point to another as in the worksheet M5. The teacher reminded them to find the shortest possible routes. Mary managed to find the shortest routes for both the questions. So, when Mary tested the route with the robot, all the team members was so impressed as they were the shortest routes.

In the activities with $3 \mathrm{D}$ Pen, she was doubtful about the steps and she observed how the team members did regularly as she was completing the activities 1,2 and 3 . When she wanted to create the pair of glasses. She observed how other team members did. They completed the glasses according to the steps: create $2 \mathrm{D}$ frames, create $1 \mathrm{D}$ lines, paste the $1 \mathrm{D}$ on $2 \mathrm{D}$, filled the $2 \mathrm{D}$ frame to become surfaces. However, she did not follow what they did. She managed to create it by simplifying the steps to three instead of four (i.e., following the previous steps, the first step is to create the outlines of the circular frames, then to create the temples separately. Then he supposed to join the temples to the circular frames before filling up the lens on the circular frames. She filled the lens immediately after the creation of the circular frames.

In the activity 1 with OZOBOT, she did not use the robot. She observed how other did and compared with the movement of the robot. She completed hers with the robot. In activity 2, as the questions were different among the team members, she checked all the answers of the other team members intuitively and advised them when she found it wrong. She coloured her worksheet quickly and intuitively.

Participant Three: Nicole

Nicole was a shy but obedient student. She was very attentive to the group while waiting for her turn to use the robot. In activity 1 and 2 of MR (see Figure $2 \mathrm{~A}$ ), she listened to the teacher's briefing and followed strictly to the instructions. However, she paid attention to how other team members ways of completing the activity in parts that she might have doubts. She was the last in the team to use the robot. She corrected her answers after verifying with the robot. In activity 3 of MR, she could answer the questions herself. And when she noticed other members had a shorter route, she modified her answers. She verified her final answer with the robot.

In the activity 1,2 and 3 with $3 \mathrm{D}$ Pen, she followed the instructions and completed the tasks. As all the team members were given the $3 \mathrm{D}$ pen and carried out the task simultaneously, she managed to observe other team members from time to time. She manged to complete activity 4 herself and during the interview, she explained how she broke the glasses into smaller steps- she remembered the steps as $2 \mathrm{D}$ surface, $1 \mathrm{D}$ lines and join $1 \mathrm{D}$ into $2 \mathrm{D}$ to for the $3 \mathrm{D}$ outline and then filled the surfaces where necessary. She also observed how others did to confirm what she did.

Finally, in her third set of activity, she used the robot to verify her answers. During the interview, she managed to show that she could remember all the codes even it was after the lesson and the instructions were asked verbally. The interview with her teacher revealed that she spoke twice as many words per minute than during other non-technology-related play.

Table 3 summarises the participants' successful learning experiences. Investigating the first dimensionsubject-tool-object-sheds light on the first research question. CT is the thought processes involved in formulating problems and their solutions (Cuny, Snyder, \& Wing, 2010). The current research dissects CT into three constructs, i.e., Algorithm, Automation and Abstraction. Table 3 reveals that the participants acquired the CT skills through their collaborative efforts see Figure 2. 
Table-3. The Responses and the Constructs of CT.

\begin{tabular}{|c|c|c|}
\hline Participants & Data Analysis & The Construct of CT \\
\hline \multirow[t]{3}{*}{ Peter } & $\begin{array}{l}\text { In the MR activity 1, he copied the } \\
\text { answers from the team members. He also } \\
\text { assimilated the skills to set the } \\
\text { movement of the robot according to the } \\
\text { questions. } \\
\text { In MR activity 2, his team members } \\
\text { guided him and pushed him to expedite } \\
\text { his tasks with robot. He spotted his } \\
\text { mistakes and acquired the skills to } \\
\text { arrange the steps (reflection). He } \\
\text { managed to complete his last question on } \\
\text { his own. } \\
\text { In the MR } 3^{\text {rd activity, Peter could write }} \\
\text { his answers independently and } \\
\text { acknowledge other member had the } \\
\text { shorter route compare with his answers. }\end{array}$ & $\begin{array}{l}\text { Algorithms } \\
\text { He learnt the algorithms with the help of the } \\
\text { robots and the collaborative efforts of the } \\
\text { team members. }\end{array}$ \\
\hline & $\begin{array}{l}\text { In activity } 2 \text { of } 3 \mathrm{D} \text { Pen, he asked and } \\
\text { observed how the team members added } \\
1 \mathrm{D} \text { lines onto the } 2 \mathrm{D} \text { rectangles. } \\
\text { The } 3^{\text {rd }} \text { activity of } 3 \mathrm{D} \text { Pen, he regularly } \\
\text { seeks assistance from his team members } \\
\text { when he formed the cuboid. } \\
\text { In activity } 4 \text { of } 3 \mathrm{D} \text { Pen, he reconfirmed } \\
\text { the steps with other team members and } \\
\text { completed the glasses on his own. } \\
\text { did in each of the activity and }\end{array}$ & $\begin{array}{l}\text { Abstraction } \\
\text { He could break the big problems into smaller } \\
\text { units. He could also remember the small units } \\
\text { and join the steps (transfer the skills) to solve } \\
\text { a similar task. }\end{array}$ \\
\hline & $\begin{array}{l}\text { In activity } 1 \text { of OZOBOT, Peter and the } \\
\text { team members discussed and said the } \\
\text { code loudly while seeing the movement } \\
\text { of the robot. } \\
\text { In activity } 2 \text { of OZOBOT, Peter } \\
\text { coloured the codes correctly. He could } \\
\text { also say the codes intuitively when he } \\
\text { saw the other members' worksheet. He } \\
\text { could also remember the codes during } \\
\text { the interview after the lesson. }\end{array}$ & $\begin{array}{l}\text { Automation } \\
\text { He learnt the codes by imitating and listening } \\
\text { to the team members. He could say the code } \\
\text { intuitively. And he remembered the codes } \\
\text { even after the lesson. He demonstrated the } \\
\text { ability to repeat the codes in different new } \\
\text { situations. He systematically transferred into } \\
\text { different situations. }\end{array}$ \\
\hline \multirow[t]{2}{*}{ Mary } & $\begin{array}{l}\text { In activity 1, Mary managed to improve } \\
\text { her answers after observing, guiding and } \\
\text { commenting on others work with the } \\
\text { robot. } \\
\text { In Activity } 2 \text {, she observed and guided } \\
\text { the other team members when they } \\
\text { compared their answers with the robot. } \\
\text { She managed to complete her works } \\
\text { even without the robot. } \\
\text { In activity } 3 \text {, she managed to find the } \\
\text { shortest routes for the } 2 \text { questions } \\
\text { correctly. During the interview with the } \\
\text { teachers, she gave the same marks to all } \\
\text { the members who could complete the } \\
\text { work. The ways and the duration taken } \\
\text { were not recorded. }\end{array}$ & $\begin{array}{l}\text { Algorithms } \\
\text { She learnt the algorithms by observing a few } \\
\text { cases of the team members. Her algorithmic } \\
\text { ability was evidenced when she could get the } \\
\text { answers correctly even without needing to } \\
\text { operate the robot in activity } 1 \text { and } 2 \text {. } \\
\text { Abstraction } \\
\text { In activity } 3 \text {, she could also transfer the } \\
\text { algorithmic skills to solve problems and she } \\
\text { was able to find the shortest routes. }\end{array}$ \\
\hline & $\begin{array}{l}\text { In activity } 1,2 \text { and } 3 \text { of } 3 \mathrm{D} \text { Pen, she } \\
\text { observed how other team members } \\
\text { completed their activity and she } \\
\text { completed hers. } \\
\text { In activity } 4 \text { of } 3 \mathrm{D} \text { Pen, she observed } \\
\text { how others completed their tasks. And } \\
\text { she did it different from them. She } \\
\text { managed to simplify it. }\end{array}$ & $\begin{array}{l}\text { Abstraction } \\
\text { She could break the big problems into smaller } \\
\text { units. She modified and simplified the } \\
\text { solutions by combining the small units of } \\
\text { steps in her own ways. She transferred the } \\
\text { skills into solving the new project. }\end{array}$ \\
\hline
\end{tabular}




\begin{tabular}{|c|c|c|}
\hline & $\begin{array}{l}\text { In activity } 1 \text {, she completed her work } \\
\text { after observing how other team members } \\
\text { did with the robot. } \\
\text { In activity } 2 \text {, She could remember the } \\
\text { codes and guided and advised the other } \\
\text { team members to get the correct } \\
\text { answers by telling the codes intuitively. }\end{array}$ & $\begin{array}{l}\text { Automation } \\
\text { She demonstrated the ability to tell the codes } \\
\text { intuitively on her team members' activities. }\end{array}$ \\
\hline \multirow[t]{3}{*}{ Nicole } & $\begin{array}{l}\text { In activity } 1 \text { and } 2 \text {, she followed strictly } \\
\text { to what the teacher said. She observed } \\
\text { how other members did to clear her } \\
\text { doubts. } \\
\text { In activity 3, she could answer the } \\
\text { questions herself. However, she noticed } \\
\text { other member's answers to find the } \\
\text { shortest route. She changed her answers. }\end{array}$ & $\begin{array}{l}\text { Algorithms } \\
\text { She demonstrated her understanding on each } \\
\text { question. She managed to develop the } \\
\text { algorithmic steps to complete the answers } \\
\text { correctly. }\end{array}$ \\
\hline & $\begin{array}{l}\text { She completed all her } 3 \text { activities (i.e., } \\
\mathrm{P} 1, \mathrm{P} 2 \text { and } \mathrm{P} 3 \text { ) by following the } \\
\text { instructions and observing others. In the } \\
\text { interview with her, she explained how to } \\
\text { break the activity } 4 \text { into smaller units. } \\
\text { She also managed to complete the } \\
\text { activity independently. }\end{array}$ & $\begin{array}{l}\text { Abstraction } \\
\text { She learnt the skills to create different objects } \\
(1 \mathrm{D}, 2 \mathrm{D} \text { and } 3 \mathrm{D} \text { objects) and when she } \\
\text { attempted activity } 4 \text {, she tried to break from a } \\
\text { big object to the smaller units. }\end{array}$ \\
\hline & $\begin{array}{l}\text { During the interview, she managed to } \\
\text { show that she could remember all the } \\
\text { codes. Her teacher had also revealed that } \\
\text { she spoke twice as many words per } \\
\text { minute during the robotic activities. }\end{array}$ & $\begin{array}{l}\text { Automation } \\
\text { She learnt and remembered to codes. She } \\
\text { demonstrated her readiness to automate the } \\
\text { instructions with the set of codes. }\end{array}$ \\
\hline
\end{tabular}

The different set of robotic toy affords different type of CT construct's knowledge construction. MT affords the construct of algorithmic skill through visualised and procedural hands-on activities, OZOBOT affords the construct of Automation through repeating the respective codes in different situations and 3D Pen allows the participants to formulate the given problem into suitable smaller steps as demonstrated by Peter, Mary and Nicole see Table 3. By enacting the tasks with the robots, the group members externalised their understanding of CT and observed by Peter, Mary and Nicole. At the same time, they also utilised the robotic toys to assist them in internalising the constructs of CT see Table 3. This, therefore, answers the first research question.

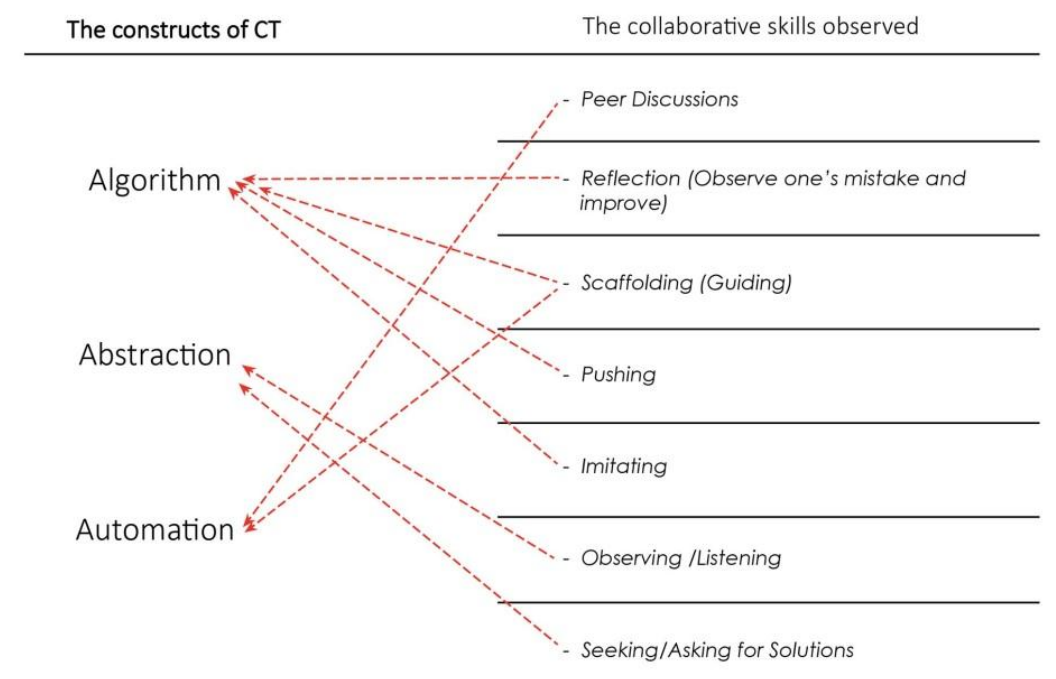

Figure-2. The skills of collaboration applied in different constructs of CT.

This multiple case study provides a more generalizable result on how robotic toys, through the learning of CT constructs merge with the collaboration of the participants iteratively to enable the CT meaningmaking processes (see Figure 2). However, as observed in the findings of the three participants, some of the interactions with the robotic toys might not result in the gaining of new knowledge in CT. This indicates that other components must be further investigated. 
Table-4. The Study of subject-community-object.

\begin{tabular}{|c|c|c|}
\hline \multirow{2}{*}{$\begin{array}{l}\text { The Construct } \\
\text { of CT }\end{array}$} & \multirow{2}{*}{$\begin{array}{c}\text { The } \\
\text { Participants }\end{array}$} & \multirow{2}{*}{\begin{tabular}{|l|} 
The interactions with other team members \\
The Findings
\end{tabular}} \\
\hline & & \\
\hline \multirow[t]{3}{*}{ Algorithm } & Peter & $\begin{array}{l}\text { Peter acquired the algorithmic skills by interacting with peers in } \\
\text { activity 2: The other team members pushed Peter to expedite his } \\
\text { answers. Therefore, they explained to him and finally he got the ideas } \\
\text { to arrange the steps. }\end{array}$ \\
\hline & Mary & $\begin{array}{l}\text { In activity } 2 \text {, she did not use the robot. She learnt the algorithmic } \\
\text { skills as she observed how other team members answered their } \\
\text { questions. She guided them to complete their questions. }\end{array}$ \\
\hline & Nicole & $\begin{array}{l}\text { The teacher commented that she communicated with team members } \\
\text { more compare with non-technological activities. }\end{array}$ \\
\hline \multirow[t]{3}{*}{ Abstraction } & Peter & He sought assistance to complete her $3 \mathrm{D}$ pen project. \\
\hline & Mary & $\begin{array}{l}\text { She observed how other created their } 3 \mathrm{D} \text { glasses. She completed it } \\
\text { with her own steps. }\end{array}$ \\
\hline & Nicole & \\
\hline \multirow[t]{3}{*}{ Automation } & Peter & $\begin{array}{l}\text { He learned how to code in activity } 2 \text { with OZOBOT. The team } \\
\text { members guided him and pushed him to complete. He managed to } \\
\text { remember the codes after the activity. }\end{array}$ \\
\hline & Mary & $\begin{array}{l}\text { She managed to observe and learn from the team members. She } \\
\text { managed to code the OZOBOT correctly even without testing her } \\
\text { answers with the robot. }\end{array}$ \\
\hline & Nicole & $\begin{array}{l}\text { She observed others answers to clear her doubts when she was } \\
\text { uncertain. }\end{array}$ \\
\hline
\end{tabular}

\begin{tabular}{|c|c|c|}
\hline \multirow{2}{*}{$\begin{array}{l}\text { The Construct of } \\
\text { CT }\end{array}$} & \multirow{2}{*}{$\begin{array}{c}\text { The } \\
\text { Participants }\end{array}$} & The systematic division of tasks and roles \\
\hline & & The Findings \\
\hline \multirow[t]{3}{*}{ Algorithm } & Peter & $\begin{array}{l}\text { The differences between activity } 1 \text { and } 2 \text { enabled Peter to acquire the } \\
\text { algorithmic skills. He learnt the basic to operate the robot in activity } \\
1 \text { and came to know the algorithmic skills in activity } 2 \text {. Finally, he } \\
\text { demonstrated his algorithmic skills in activity } 3 \text {. }\end{array}$ \\
\hline & Mary & $\begin{array}{l}\text { The different level of learning activities in activities } 1,2 \text { and } 3 \text { allowed } \\
\text { Mary to know the concepts of algorithms. Finally, she could transfer } \\
\text { the algorithmic skills to solve the problem of finding the shortest } \\
\text { routes. }\end{array}$ \\
\hline & Nicole & $\begin{array}{l}\text { She followed the teacher's instructions strictly to complete the tasks } \\
\text { of the three activities. During the interview, she demonstrated her } \\
\text { understanding the algorithms to achieve the shortest routes. }\end{array}$ \\
\hline \multirow[t]{3}{*}{ Abstraction } & Peter & $\begin{array}{l}\text { In the } 4^{\text {th }} \text { lesson, he applied the knowledge he learnt from the } \\
\text { previous three lessons to develop the object. He managed to explain } \\
\text { the steps during the interview. }\end{array}$ \\
\hline & Mary & $\begin{array}{l}\text { In her } 3 \mathrm{D} \text { pen activity, she learned the individual steps by observing } \\
\text { others. She reorganised the individual steps and created her new } \\
\text { sequence by simplifying the steps to three instead of four. }\end{array}$ \\
\hline & Nicole & $\begin{array}{l}\text { She decomposed the glasses into smaller parts, i.e., circles, 1D } \\
\text { straight lines with bending tails. }\end{array}$ \\
\hline Automation & Peter & $\begin{array}{l}\text { In the first activity of OZOBOT, Peter had not acquired the CT skill, } \\
\text { he could follow as the worksheet was the same with other members. } \\
\text { The } 2^{\text {nd }} \text { activity of OZOBOT enabled him to learn as the worksheets } \\
\text { were different among the members. }\end{array}$ \\
\hline
\end{tabular}

In the second dimension, subject-community-object, the community setting provides the context in promoting the participant's CT learning through their articulated interplay during the activity. When children play in group, they learn by doing with the group members (Bers, 2018). In activity of MT, Peter learned the CT skills only in activity 2 when the group members guided him as he was enacting the robots to complete the task see Table 4. CT is a process-based skill, it happened in time, not in space. The continuous 
guidance of the group members facilitated the learning. For Nicole, the teacher commented that she spoke twice as many words per minute during the activity. She learned the CT skills through her frequent communication with the group members. Mary observed the ways how to code the OZOBOT sequentially and she demonstrated her ability to produce the answer correctly. She had also demonstrated her ability to practise the CT by observing and communicating with the group members and to produce a solution that was different from them in her $3 \mathrm{D}$ pen activity. The current research results show that the community setting has an absolute effect in the constructs of the CT learning see Table 4.

In the third dimension, subject-division of labour-object, the progressively introduction of tasks in the activities were studied. In MT three different level of activities, activity 1 introduced the steps for the participants to follow; activity 2 required them to design and activity 3 intended to find the shortest route. At the same time, all the participants had the same questions in activity 1 but not in activity 2. The division of activities of different tasks enabled the participants to acquire the CT skills (see Table 5). In 3D pen activities, the 3 beginning activities guided the participants to create the $3 \mathrm{D}$ glasses. All the participants acquired the CT skills and Mary demonstrated her ability to transfer her knowledge. The skill of abstraction enables people to glean relevant information and discard irrelevant data from complex systems (Shute, Sun, \& Asbell-Clarke, 2017; Wing., 2010). In the 2 OZOBOT activities, Peter demonstrated his learning took place in activity 2 when the individual members had different questions. The participants exhibited different personalities, nevertheless, it was noticed that all of them managed to complete the tasks.

Table-6. The Study of subject-rules -object.

\begin{tabular}{l|l|l}
\hline $\begin{array}{l}\text { The } \\
\text { Construct } \\
\text { of CT }\end{array}$ & $\begin{array}{l}\text { The } \\
\text { Participants }\end{array}$ & $\begin{array}{l}\text { The rules/norms (explicit and implicit) that regulate actions } \\
\text { and interactions } \\
\text { The Findings }\end{array}$ \\
\hline Algorithm & Peter & $\begin{array}{l}\text { The time limit of the activity is 15 minutes. In activity 2, Peter was } \\
\text { pushed and guided by his team members. The situation helped him } \\
\text { to acquire the algorithmic skills. }\end{array}$ \\
\hline Abstraction & Peter & $\begin{array}{l}\text { In activity 1 and 2, the rule to guess the answers before to use the } \\
\text { robot to execute the steps allowed Mary to acquire the algorithmic } \\
\text { skills as demonstrated in activity 2 and 3. }\end{array}$ \\
\hline & Mary & $\begin{array}{l}\text { The rule to share the robot and to let the members in the group to } \\
\text { take turn to use the robot allowed her to learn the algorithmic skills. }\end{array}$ \\
\hline & Nicole & $\begin{array}{l}\text { In the 3D pen activity, the team members started the activity } \\
\text { simultaneously. This allowed Nicole to observe how others } \\
\text { completed their work. She learned by observing and manage to } \\
\text { complete hers. }\end{array}$ \\
\hline Automation & Peter & $\begin{array}{l}\text { The rules of the worksheets designed to allow the learners to } \\
\text { practise the combination of codes in facing different situations. The } \\
\text { children learnt the codes promptly. They remembered the } \\
\text { commands and transferred them to other situations. }\end{array}$ \\
\hline & Mary & $\begin{array}{l}\text { She managed to complete the questions quickly and she was so } \\
\text { confident with her answers even in the first attempt. The consistent } \\
\text { design of the worksheets also made her so confident. }\end{array}$ \\
\hline
\end{tabular}

In the fourth dimension, subject-rule-object, the rules that regulate the actions and interactions of the participants were studied. In the study of the algorithmic skills, the time limit of 15 minutes for each activity made the team members to guide and push Peter to complete his work (see Table 6). The rule of guessing the answers before the team was given the robot allowed Mary to think reflectively and acquired the algorithmic skills. And in the same task using MT, as they took turn to utilize the robot, Nicole managed to observe and learn from the team members when it was not her turn. On the other hand, in the $3 \mathrm{D}$ pen activity, each member had his/her pen allowed Nicole to utilize the pen and observed how other team members did it. These rules regulated implicit and explicit actions and interactions of the participants and resulted in acquiring the CT skills.

The analysis of the dimensions that might affect the learning of CT skills are summarised as follows.

- There is no particular technology that is developed for educational purposes (Oztürk \& Calingasan, 2018). Unlike other technologies, the educational robotics toys are designed with special learning purposes. Choosing developmentally suitable robotics resources is important in teaching children CT skills especially at the preschool level. In the current research, it has evident that MR is suitable for developing the concept of Algorithm, 3D pen for Abstraction and OZOBOT for Automation. The 
results, however, contradict previous study, which indicates the minimum age at which lessons about abstraction is appropriate (Rijke, Bollen, Eysink, \& Tolboom, 2018).

- CT entails a whole set of mental tools that enable people to represent problems systematically (automation), reduce difficult problems into small solvable small tasks (abstraction) and compose sequence of steps that are executable by a machine (Algorithm) (Chen et al., 2017; Wing, 2006). These skills are of the metacognitive level. They happen in time and not in space. To teach the skills in the classroom, it takes transformation of thinking from the world of sight. It is evident that a new design followed by new pedagogical approach is needed.

- Due to the emergence of the technology and the educational robotics toys, coding merely requires children to draw lines with the combination of different colours like OZOBOT, algorithmic sequencing as in MT by pressing buttons and use 3D pen as a whole new way to create and fix things easily and It lifts the children's imagination off the page. These toys develop children to think like the robot (computer) and hence could use the computer to express themselves in a fluent way and they also remove cognitive demands, for instance, on writing programming codes.

- The setting of rules of the activities intended to engage the participants to have active interaction with the CT through the operation of the robot-e.g., the limit of 15 minutes.

- The various levels of the activities in developing the construct of CT focus on the type of the construct. For example, in the MR, activity 1 to introduce the direction, activity 2 to sequence the steps, and activity 3 to solve a problem, i.e., the shortest route.

- To allow the robotics toys serve as effective tools in learning CT, the interplay and the sequence of the different dimensions of the activities should be considered. Based on the current research findings, It is necessary to establish a more robust framework to incorporate elements to consider in designing CT activities (Granberg \& Olsson, 2015).

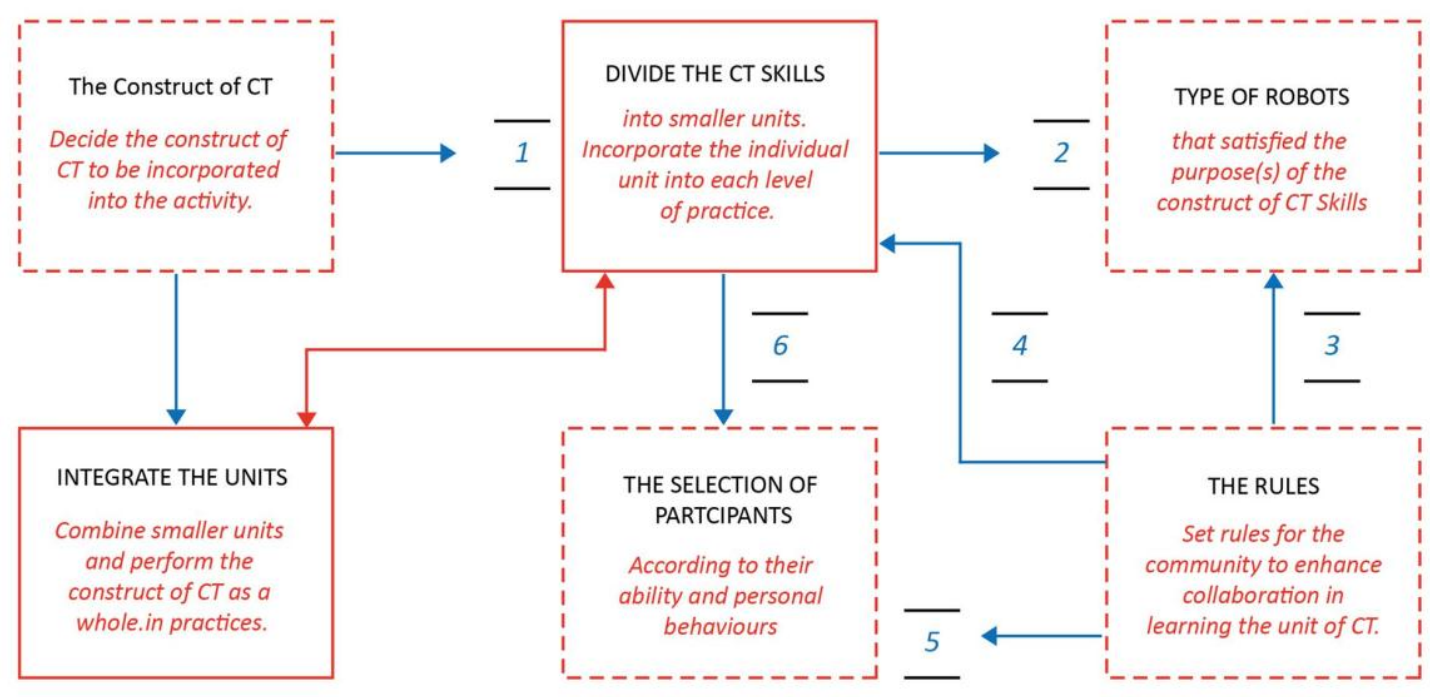

Figure-3. The Framework to Design CT Activities with Educational Robotics Toys.

The findings of research question two are, indeed, analogous to a jigsaw puzzle. Through application of the activity theory, the four dimensions of analysis served as fundamental pieces of the puzzle. Once these pieces were fitted together, the answer to research question two was answered in totality. The summarised framework is presented in Figure 3. As indicated in Figure 3, to design activities to learn the skills of CT, decide the construct of $\mathrm{CT}$ as the objective of learning in the activity, subsequently, there are 6 steps to consider:

1. Divide the construct into smaller units.

2. Decide the type of tool, i.e., a robotic toy that can perform the construct of CT.

3. Set the rules for the participants in a group as guides so that the individual participants will response collaboratively and gain the skill of the construct of CT.

4. Study the relationship between the rules to unit of the construct of CT understudied.

5. Study the relationship between the rules and the participants.

6. Study the relationship between the participants and the unit of CT understudied.

7. After all the units are considered, change the unit to the combined units as a whole and repeat step 2 to step 6 . 


\section{Discussions}

Consistent with other recent research, children as young as four can play to learn a range of concepts, including CT (Bers., Flannery, Kazakoff, \& Sullivan, 2014; Chen et al., 2017). Meanwhile, there is an overwhelming argument that educational robotics are increasingly appearing in educational settings, being considered a useful supporting tool for the development of cognitive skills, including CT, for students of all ages. This study extended the research findings to the context of the elementary classroom. It helps to articulate the connection between CT constructs and all academic disciplines, developing content to support integration into curricula.

Given that CT focuses on problem solving, it is essential that the learners could accurately conceive the desired ability, elicit and using the knowledge to produce the expected results. When learners work together in cooperative teams achieve higher level of thoughts, it creates the opportunity to discuss about the subject (see Figure 2), be responsible about their learning as with Nicole, Peter and Mary (see Table 3), and therefore lead to create crucial thinkers (Totten, Sills, Digby, \& Russ, 1991). This leads to a transition from individual efforts to collaboration, and from independence to community. It is through ubiquitous responses and talking that learning occurs (Gerlach, 1994).

Further investigation on the other components of the classroom activity has revealed that the rules of the classroom activity, the community, the division of the tasks and also the selection of the participants of the group will affect the learning of the participants. The framework to design the classroom activity for CT has also been derived from the research findings as in Figure 3.

While the current study extended our understanding of the classroom activity design, it also highlighted some problems. The study did not look into how the best way to combine personality traits and their learning abilities (e.g. homogenous or heterogeneous group) to support effective interactions among the group members. Mary, with her good social assertive skills, was able to design the 3D glasses in her own ways after observing how other members in the group did. Peter was asking questions spontaneously of his teammates in the group whenever doubts arose in his mind. He could code the mouse robot only in the second activity after communicating with his group members. The study has not investigated the optimal combination of team members according to their personal traits and learning abilities. Additional work and collection of data would be worthwhile to generalise the results. On the other hand, Table 2 summarises the findings of the participants' experiences in learning CT. The findings have reflected teachers would be more interested in the final learning outcomes at a more general level rather than the process of learning. In Mary's case, the teacher gave the equal marks to those who can complete the work without considering the ways and the duration on how they did it. A more specific but simple guidelines could be established to address the important aspects of the CT learning activities. Future research could focus on more specific views to improving the current framework as in Figure 3.

Further, the kindergarten encountered difficulties in training teachers in addressing the concept of CT. Partly, it is due to the concept of CT in early education has not yet been well developed and the perception of the teachers that lack of time for introducing a new subject in the curriculum. Doubt must be acknowledged as to the general validity and availability of robots suitable for young children's classroom learning.

\section{Conclusions}

The interest of computing in early education has never been as high as now. Many countries have or are about to introduce CT in some form into their national curricula. This paper synthesises the relevant classroom activity designs in addressing CT as a general term that involves solving problems, entails a whole set of mental tools that enable people to reduce complex problems into readily solvable subtasks and composes algorithms that are executable by machines. We are deeply concerned with what students learn in this curriculum by integration of robotic toys into early education. What we deem more important is to assist our students to acquire certain CT skills and thinking patterns that are readily transferable, and thus conducive, to their future learning and problem solving in computing related subjects or even everyday reasoning.

There is a trend toward collaboration in $21^{\text {st }}$ century. Individuals need increasingly to think and work together in societies, on critical subjects (Laal, Khattami-Kermanshahi, \& Laal, 2014; Welch, 1998). Movements are currently underway to reform the practices of teacher-directed paradigm toward a studentcentred learning. There is a concerted effort to introduce collaborative learning for developing CT competencies in early education classrooms. The study proposes the framework to design activities that cultivate the efforts of group work and community. It highlights aspects to be considered when designing the activities in the classrooms.

There has been a growing recognition that educational robotics is an effective tool for providing students with opportunities to learn computational thinking skills and concepts (Catlin \& Woollard, 2014; Eguchi, 2016). Although the Education Robotics Applications (ERA) Principles (Catlin \& Woollard, 2014) explains how robots help students learn and the benefits of educational robots to teachers, the current study also postulated it is important to identify the type of construct as it varies with different type of robot and activity design. It is also important to address the underlying cognitive and developmental processes of the constructs of CT for the school to evaluate the type of robots to adopt in the classroom CT learning activity. 


\section{References}

Bers, M. U. (2018). Coding as a playground. New York: Routledge.

Bers., M. U., Flannery, L., Kazakoff, E. R., \& Sullivan, A. (2014). Computational thinking and tinkering: Exploration of an early childhood robotics curriculum. Computers $\&$ Education, 72, 145-157.Available at: http://dx.doi.org/10.1016/i.compedu.2013.10.020.

Catlin, D., \& Woollard, J. (2014). Educational robots and computational thinking. Paper presented at the 4th International Workshop teaching Robotics, Teaching with Robotics, Padova, Italy.

Chen, G., Shen, J., Barth-Cohen, L., Jiang, S., Huang, X., \& Eltoukhy, M. (2017). Assessing elementary students' computational thinking in everyday reasoning and robotics programming. Computers \& Education, 109(1), 162175 .

Cukurova, M., Luckin, R., Millán, E., \& Mavrikis, M. (2018). The NISPI framework: Analysing collaborative problemsolving from students' physical interactions. Computers \& Education, 116, 93-109.Available at: https://doi.org/10.1016/j.compedu.2017.08.007.

Cuny, J., Snyder, L., \& Wing, J. M. (2010). Demystifying computational thinking for non-computer scientists. Retrieved from: https://www.cs.cmu.edu/ CompThink/resources/TheLinkWing.pdf

Eguchi, A. (2016). Computational thinking with educational robotics. Paper presented at the SITE 2016, USA, Savannah, GA, United States.

Engeström, Y. (1987). Learning by expanding. An activity theoretical approach to development research. Helsinki: Orienta Konsultit

Gerlach, J. M. (1994). Is this collaboration? In K. Bosworth \& S. J. Hamilton (Eds.), Collaborative Learning: Underlying Processes and Effective Techniwues, New Directions for Teaching and Learning (pp. 5-14). San Francisco, USA: Jossey-Bass Publishing.

Granberg, C., \& Olsson, J. (2015). ICT-supported problem solving and collaborative creative reasoning: Exploring linear functions using dynamic mathematics software. The Journal of Mathematical Behavior, 37, 48-62.Available at: https://doi.org/10.1016/j.jmathb.2014.11.001.

Harangus, K., \& Kátai, Z. (2017). Algorithmic thinking vs. text comprehension. Paper presented at the 11 th International Conference Interdisciplinary in Enginnering, INTER-ENG 2017, Tirgu-Mures, Romania.

Kurilovas, E., \& Dagiene, V. (2016). Computational thinking skills and adaptation quality of virtual learning environments for learning informatics. International Journal of Engineering Education, 32(4), 1596-1603.

Laal, M., Khattami-Kermanshahi, Z., \& Laal, M. (2014). Teaching and education; collaborative style. Procedia-Social and Behavioral Sciences, 116, 4057-4061.

Manches, A., \& Plowman, L. (2017). Computing education in children's early years: A call for debate. British Journal of Educational Technology, 48(1), 191-201.Available at: https://doi.org/10.1111/bjet.12355.

Merriam, S. B. (1988). Case study research in education-a qualitative approach. San Francisco, CA: Jossey-Bass Publishers.

Oztürk, H. T., \& Calingasan, L. (2018). Robotics in early childhood education: A case study for the best practices. In H. Özçinar, G. Wong, \& H. T. Öztürk (Eds.), Teaching Computational THnking in Primary Education (pp. 182200). Hershey, PA: IGI Global.

Rijke, W. J., Bollen, L., Eysink, T. H., \& Tolboom, J. L. (2018). Computational thinking in primary school: An examination of abstraction and decomposition in different age groups. Informatics in Education, 17(1), 77-92.Available at: https://doi.org/10.15388/infedu.2018.05.

Shute, V. J., Sun, C., \& Asbell-Clarke, J. (2017). Demystifying computational thinking. Educational Research Revierw, 22, 142158.Available at: https://doi.org/10.1016/j.edurev.2017.09.003.

Sung, J. (2018). How young children and their mothers experience two different types of toys: A traditional stuffed toy versus an animated digital toy. Journal of Research and Practice in Children's Services, 47(2), 233-257.

Totten, S., Sills, T., Digby, A., \& Russ, P. (1991). Cooperative learning: A guide to research. New York, USA: Garland Publishing.

Welch, M. (1998). Collaboration: Staying on the bandwagon. Journal of teacher Education, 49(1), 26-37.Available at: https://doi.org/10.1177/0022487198049001004.

Wing, J. M. (2006). Computational thinking. Communications of the ACM, 49(3), 33-35.

Wing., J. M. (2010). Computational thinking: What and why? Computer science department. Pittsburgh, PA: Carnegie Mellon University.

Yin, R. K. (2014). Case study research- design and methods. London, UK: SAGE Publications Ltd. 